\title{
CHINA IN AFRICA: EXPLORING THE DIVIDENDS AND THE CHALLENGES
}

\section{Sheriff Ghali Ibrahim, Adie Edward and Nwokedi Lawretta Obiagelli}

\author{
Department of Political Science \& Int'l Relations, University of Abuja
}

Email: sherfboy@yahoo.com; Phone: +234-7063372013

\begin{abstract}
Cite this article:
Sheriff G.I., Adie E., Nwokedi L.O. (2021), China in Africa: Exploring the Dividends and the Challenges. Journal of Advanced Research and Multidisciplinary Studies 1(1), 129-141. DOI: 10.52589/JARMSIFAMX5UE.
\end{abstract}

\section{Manuscript History}

Received: 26 June 2021

Accepted: 27 July 2021

Published: 11 Aug 2021

Copyright $\odot 2020$ The Author(s). This is an Open Access article distributed under the terms of Creative Commons AttributionNonCommercial-NoDerivatives 4.0 International (CC BY-NC-ND 4.0), which permits anyone to share, use, reproduce and redistribute in any medium, provided the original author and source are credited.
ABSTRACT: The study examined China's presence in Africa, the warm reception it has received from African states into the continent, the benefits Africa stands to gain from the relationship as well as other emerging issues. In order to arrive at a reliable outcome, the work utilized descriptive research design and obtained data from secondary sources such as textbooks, journals, research articles, magazines, newspaper, the internet, etc. While the analysis of the data was enhanced through the tool of content analysis, the linkage approach, which emphasizes the important connection between the domestic factor and the states actions and decisions at the international scene, was adopted as framework for the study. In all, the findings suggested that there are a lot of benefits accruing to Africa as a result of its relation with China. These were highlighted and discussed under various headings covering investment, training and technology transfer, scholarship, free interest loans, forum on China-Africa Cooperation (FOCA), job creation and skill acquisition. The study also pointed out the flip sides of China's engagement in Africa. These issues, which are also emerging, include: human right abuse, Job loss due to competition, spying accusation and loss of confidence in China, wrong political influence and the piling up of debt traps through interest free loans. Some recommendations were made to ensure that both parties China and Africa- mutually benefit from this engagement. Thus: Efforts should be made to sustain the relationship in such a way that both sides can benefit mutually. This could be attained by being opened and transparent in all the dealings by both parties; African states should seize the current opportunity of their engagement with China to develop their needed infrastructure and acquire the necessary skills and knowledge for their economic and industrial growth because delay may be dangerous; China should write its name in the annals of African technological breakthrough history by genuinely transfer more technology to African for self-reliance and development; All the issues considered as flip side in this study must be looked into, especially the issues of human rights abuse, wrong political influence and piling up of debt for the unborn generations; Finally, we believe that there is no engagement anywhere in the world that is devoid of issues but the ability to resolve them is what defines the texture and the contour of such engagement. Therefore, they must work hard to settle any issue that may arise between them, including the spying allegation leveled against China.

KEYWORDS: China, Africa, Investment, Free Loans, Forum on China-African Cooperation, Human Rights Abuses, African Union, Scholarship, Linkage Approach. 


\section{INTRODUCTION}

It is no longer news that the courtship between China and Africa has assumed a new dimension since 2000 following the resurgence of China in Africa with some programmes that have helped to solidify the relationship. This development has seen China spending billions of dollars on railways, roads and power infrastructure in Africa; awarding scholarships to citizens to pursue education in any chosen field in Chinese universities; transferring technology to African states; promoting trade, granting free interest loans as well as cancelling debts owed by African states to the tune of over 10 billion Dollars (Ambe-Uva 2014:17-18). Africa, on her part has reciprocated this gesture by not only warmly embracing China as confirmed by the former President of Zimbabwe, Robert Mugabe in Moyo and Mdlongwa (2015:77): "We have turned east where the sun rises, and given our backs on the West where it sets", but has also gone ahead to grant China free access to its oil and gas sector and other mineral resources which are useful to the growth of Chinese economy and industries (Marqures and Spanakos, 2014:148). Nonetheless the free access to African resources appears to have generated arguments from some scholars who claim that China's sole interest in Africa is about resources. One of such claims emanates from The Economist (2006:53), which notes that unlike in the 1950s and 1960s when China supported African liberation movements and built railways, educated African students and sent them doctors for the sake of gaining influence, what China wants now in Africa is "commodities more than influence". Amasa, Monkam and Viegi (2016) mention resource motive as an important factor in China's role in Africa. Another source has argued that China is in Africa for businesses that are beneficial to either individuals or to China's national interest (Popup Chinese, 2013). But the big question is whether China's presence in Africa is all about commodities- oil and other materials resources? How did China become an important point of global reference in terms of its role in world affairs, including Africa? These questions are very pertinent in that our understanding of China's role in Africa can best be gleaned from the overall China's global role as well as the internal dynamics which give her that leverage. There is no doubt that China needs African commodities for her industries but that alone is not enough explanation on why China is in Africa. African also needs China to assist her in finding solutions to her numerous challenges, because as once noted by the Chinese Consul in Lagos, China has come to champion "global governance, free trade and open global economy. At present, China contributes more than $30 \%$ of global economic growth, accounts for $70 \%$ of global poverty alleviation activities being the largest source of peacekeeping personnel and second largest contributor to the UN peacekeeping budget" (Xiaoliang cited in Anyagafu, 2018). This goes to show how important the both sides are to each other. However, China did not just come to this significance overnight; it was via some painstaking internal reforms that were undertaken between 1949 and 2000s which resulted in economic growth and prosperity. Thus, according to Hirst (2015) whose study draws basically on the NBER Working Paper Series (2015), a decade after the emergence of modern China in 1949, substantial growth in per capita GDP was witnessed due to the first five-year plan by China " 6000 Soviet advisers helped establish and operated the 156 large scale capital intensive soviet assisted projects". The high productivity and industrialization that the plan brought were, however, slowed down by the "Great Leap Forward" (1958-1962) which banned incentives and restricted markets, forcing the government to abandon it in 1962 and in four years GDP growth bounced back again (Hirst, 2015).

Nonetheless, it was at the Third Plenary Session of the $11^{\text {th }}$ Central Committee of the Party in December, 1978 that the sustainable pathway for the country's economic growth was set. As a 
result, farmers were allowed to sell their produce in local markets. By 1979 China introduced Foreign Equity Joint Venture Law which helped to increase the GDP from a yearly average of 6\% from 1953-1978 to 9.4\% between 1978 and 2012 (Hirst, 2015). This was followed by reopening of the Shanghai Stock Exchange, after over 40years, in 1990. China subsequently joined the World Trade Organization (WTO) in 2001(OECD, 2015:22). All this helped to advance its economic growth. The entrance into the WTO especially, helped to promote China's "Going Global" strategy that encourages China's firms to participate in foreign investment which in the case of Africa it has been majorly in "oil, gas, infrastructure, telecommunication and most recently food production" (Marqures and Spanakos, 2014:150).

The study, therefore, will consider the various gains accrue to African states from this engagement as well as the flip side or challenges to it.

\section{Statement of the Problems}

China's presence in Africa has attracted mixed reactions in recent times. While some have considered the development as one of the best things that has happened to the continent in view of the magnitude of economic benefits such as infrastructure development in road networks, railways, employment opportunities, steel development, trade, free loans, transfer of technology etc which African states stand to gain from the Chinese government and companies. Some have a contrary view. To them, China represents a modern-day imperialism whose interest is the exploitation of African resources especially oil, gas and other raw materials, to enhance the continuous growth of its industrial and economic sectors back home. They accuse China of perpetrating corruption; retarding development, innovation and diversification of economy; blocking progress on human rights and; supporting dictators in Africa. Because of this, they maintain Africa has never witnessed the expected massive development despite China's celebrated presence. The paper intends to highlight and discuss the major points raised by these groups with a view to understanding the major impacts of China's presence in the continent of Africa and what needs to be done to improve the relationship in such a way that both sides can benefit mutually.

\section{Objective of the Study}

Broadly speaking, the main objective of this study is on China's presence in Africa. Other specific objectives are as follows:

1. To examine those factors that propelled China's engagement in Africa as well as African response;

2. To discuss the dividends or benefits African states stand to gain from China's presence in Africa by looking at the positive impacts of the engagement and;

3. To highlight those emerging issues (flip side or challenges) that can impact negatively on African society in the course of this relationship and thereby suggest possible ways on how to address them for the benefit of the two parties. 


\section{Research Methodology}

The research adopts a descriptive design. The reason is to enable us to gather useful data relating to the subject under investigation and present them clearly and understandably for public consumption. Consequently, we generated data mainly from secondary sources such as textbooks, journals, articles, newspaper, magazine, inaugural lecture, online materials etc., while content analysis proved rewarding in our analysis of the data collected.

\section{THEORETICAL FRAMEWORK}

The linkage approach has been adopted as a framework to analyze China's engagement in Africa as well as African response to this development. The Linkage approach is one that tries to explain the action or decision of states in the international scene by establishing a link (connection) between the domestic situation of a country and its external environment. In other words, what happens to a country internally could also dictate her action and inaction on the global scene. According to Rosenau, who first coined the concept to analyze American foreign policy, linkage concept is defined as "any recurrent sequence of behavior that originated in one system and is reacted to in another" (Rosenau 1967 in Dauda, 2015:26). The approach has proved useful in analyzing, adequately, the extent to which interaction between domestic and external milieus can affect foreign policy formulation as well as identifying the extent to which specific forces can positively or otherwise impinge on the achievement of a given policy (Dauda 2015).

This approach seems to fit perfectly in the analysis of China's decision to engage Africa as well as African response to the development. Domestically, China, for instance, has grown economically due to some series of reforms it embarked on previously, thereby making expansion beyond its shore inevitable. Also, since China's economy became stable internally, it decided to join the WTO in 2001 and later adopted the "Going Global" Strategy which saw its firms investing in countries of the world, including Africa, to enhance her "global power status" (Marqures and Spanakos, 2014). Moreover, it's been argued that China encountered several hiccups in getting to its economic el dorado. This domestic experience has influenced its move towards Africa which is currently facing the same predicaments China went through over 40 years ago (The Herald, 2017). There is also a claim that in China there is a shrinking arable land and the farming population is declining, this has forced China to increase overseas farming in recent years (Jiao, 2015:1). Besides, China also wants oil and other material resources to feed its industries and sustain its economy back home. These are some of the domestic conditions that influenced China's engagement in Africa. On the African side, the approach provides a clear explanation on why Africa embraced China. Thus, Africa domestically is in need of infrastructure such as roads, railways, stable power supply as well as loans or credits to finance its development projects. Africa also needs technology and skills to exploit the enormous resources domiciled on its soil. Africa still needs people to buy its oil and other raw materials so it can fix the education sector, etc. all these domestic circumstances had actually influenced African states to act the way they did in embracing China. 


\section{RESULTS AND DISCUSSION}

\section{The dividends of China in Africa}

On a general note, China's presence in Africa has proved beneficial to African in several ways. Some of these benefits can be gleaned from the reports from different sources as we discussed in this study. It is these dividends that have helped in sustaining the relationship despite the few challenges that have greeted the courtship. Let's now consider these dividends in detail.

\section{Forum on China-Africa Cooperation (FOCAC)}

Since 2000, the cordial relationship that exists between China and African continent has taken to a new level following the establishment of FOCAC. According to Sun (2018) "FOCAC was basically an institutional platform and mechanism for the economic cooperation between China and African States". The forum has held a total of six summits on three-year intervals since its formation in the year 2000. The 2018 Summit is slated to be held in Beijing, China. During the 2015 summit at Johannesburg, South Africa, Xi, Jiping, the Chinese President promised a \$60 million funding commitment to ameliorate the challenges associated with economic and social development in Africa, such as industrialization, agricultural modernization and infrastructure (Sun, 2018). Ibrahim and Aliyu, (2016) have argued that "FOCAC" has recorded numerous successes and achievements. Thus, apart from the "cancellation of RMB10.9 billion debts for 31 Africa country "during the first summit in 2000, the cooperation has achieved more in other areas, specifically during the third summit. These include: doubling Chinese assistance to African countries on the 2006 basic include: provided African Countries with US $\$ 3$ billion in concessional loans and US\$2 billion in preferential export buyer's credit: established ChinaAfrica development fund which invested more than US\$4,500 million in 27 project, cancelled 154 debts owed by 33 Africa Countries, increased the number of export item to China while enjoying zero tariff treatment to 478: started the construction of six economic, and trade cooperation zones in Africa Countries, increased the number of Chinese government scholarship to Africa Countries sent 104 senior Agro technology experts to Africa, stated the constitution of 10 Agro Demonstration centres. Built 28 new hospitals, opened 30 malaria preventive and treatment centers and sent 1,200 medical workers and 300 Chinese youth volunteers to work in Africa (Ibrahim and Aliyu, 2016:131).

\section{Donation of Headquarters to African Union (AU)}

China has equally assisted in providing befitting Headquarters for Africa supranational organization- The Africa Union (AU). The edifice which was built between September, 2009 and December, 2012 in Addis Ababa, the capital of Ethiopia, came as a sigh of relief to the continental body over its challenge of office accommodation (Linyan, 2012). According to the above source, the mainframe of the building is 99.9 meter high, signifying the date - September 9, 1999 when the organization of Africa Unity (OAU) voted to become the Africa Union. The new building, commonly referred to as China's "gift" to Africa has a conference centre whose floor covers about 50 square meters, and with a large conference hall of 2,550 seats, five news conference rooms and two VIP rooms among several facilities (Linyan, 2012). There is no doubt that the building which was constructed, furnished and freely donated to AU is a significant "gift" that has further enhanced the relationship between China and Africa. 


\section{Loans}

In the area of loan facilities, African states have also benefited from China. For instance, a report by China-African Research Institute (CARI, 2018) indicates that "from 2000-2015, the Chinese government, banks and contractors extended US\$94.4 billion worth of loans to African government and State-Owned Enterprise (SOES)". Another report by Brautigam (2013) reveals that "from 2010 to May 2012, China approved concessional loans worth a total of US $\$ 11.3$ billion for 92 Africa projects". Also beginning from 2000 up to 2014, "almost 5\% of these loans from China to Africa went into the two biggest sectors - transportation and energy" the transportation sector which covers road and railways mainly gulped the sum of $\$ 24.2$ billion while the energy sector; electricity got $\$ 17.6$ billion (The Herald, 2017).

The loans usually come from different sources such as the China's Official Export Credit Agency, China Export-Import Bank (Eximbank) the State-owned Enterprises (SOEs), Industrial and commercial Bank of China (ICBC) etc. Accordingly, it has been estimated that between 2000 and 2014, China Eximbank has provided nearly USD\$59.0 billion in official, medium to long term finance to African governments and state-owned enterprises. China Development Bank has lent a further USD \$13.7 billion to official African borrowers and their SOEs, while ICBC has provided at least USD\$3.3. The Chinese government and other stateowned banks have distributed at least USD $\$ 3.5$ billion in zero-interest and other loans" (Brautigam and Jyhjong, 2016:7). The above authors also reveal that within the period of 15 (2000-2014), Angola tops Chinese loans to Africa with USD\$21.2 billion. Ethiopia follows withUSD\$12.3 billion, Sudan USD\$5.6billion, Kenya USD\$5.2 billion and US\$4.9billion (Brautigam and Jyhjong, 2016:9). All these loans have assisted Africa to finance some of its development projects like roads, railways, light etc. For instance, in 2014 the Eximbank's \$3.6 billion two trenches loan was used for the construction of Standard Gauge railway from Mombasa to Nairobi in Kenya and another \$3billion dollars was for Addis Ababa - Djibouti railway (Ehinzuelen, 2017:4).

\section{Scholarship for Students of Africa Origin}

China's presence in African has also birthed a number of scholarship programmes for African students. Breeze and Moore (2017) has noted that in the space of less than 15 years the number of African students has grown 26-fold - from just below 2000 in 2003 to almost 50,000 in 2015 thereby replacing US and UK as destinations for Anglophone African students. The detail of this is contained in Table 1 below:

\section{Table 1: International Students at Chinese Institute of Higher Education}

$\begin{array}{lll}\text { Year } & \text { African Students }(\% \text { Total) } & \text { Total International Students } \\ 2003 & 1,793(2 \%) & 77,715 \\ 2004 & 2,186(2 \%) & 110,844 \\ 2005 & 2,757(2 \%) & 141,087 \\ 2006 & 3,737(2 \%) & 162,695 \\ 2007 & 5,915(3 \%) & 195,503 \\ 2008 & 8,799(4 \%) & 223,499 \\ 2009 & 12,436(5 \%) & 238,184 \\ 2010 & 16,404(6 \%) & 265,090 \\ 2011 & 20,744(7 \%) & 292,611\end{array}$




$\begin{array}{lll}2012 & 27,052(8 \%) & 328,330 \\ 2013 & 33,359(9 \%) & 356,499 \\ 2014 & 41,677(11 \%) & 377,054 \\ 2015 & 49,792(13 \%) & 397,635\end{array}$

Sources: Chinese Ministry of Education cited in Breeze and Moore (2017)

In the above table, the total number of African students in Chinese Institute of Higher Education grew from a meagre number of 1,793 representing $2 \%$ of the total international students in 2003 to 49,792 representing $13 \%$ of the overall international students in 2015. Breeze and Moore (2017) explained that "this dramatic increase in students from Africa can be explained in part by the Chinese government's targeted focus on African human resource and education development" which began in 2000. Thus, in 2015, for instance "China pledged to provide 30,000 scholarships to African students by 2018". One thing about Chinese Scholarship programme for African students is that unlike the west, China does not insist that the students should remain there after graduation. Rather they returned home with their new education and skills to develop their countries (Breeze and Moore, 2017). This, in a way, has helped to prevent brain-drain, which Ogbu (2018:26) considered as one of the "exogenous factors" responsible for the continued underdevelopment of African society.

\section{Investment}

China has invested severally in Africa. Thus, starting from the 1960s when the country invested the sum of US\$400 million in the major rail project- Dar Es Salaam to Kapiri Mposhi Line between Zambia and Tanzania referred to as the Project TAZARA line (VOA, July, 2018), China's investments in Africa today, are in billions of dollars. From available reports, between 2009 \& 2012, China investment in Africa has grown by $20.5 \%$ on an annual basis. While in 2014 five African countries - Algeria, Zambia, Kenya, Republic of Congo and Nigeria were the top destinations of Chinese Direct Foreign Investments (DFI) in Africa, Algeria alone accounted for over 20\% (China-Africa Trade and Economic Cooperation, 2013; CARI, 2018). Cumulatively, according to Brautigam (2013) Chinese DFI to Africa now amounts to US\$ 21 billion of which manufacturing investment is at US\$3.43 billion. Besides, Chinese indigenous companies such as Huawei and Zhongxing Telecommunication Equipment Company Limited (ZTE) are well known in the telecom industries in Africa. Huawei alone is said to have more than 30 branches spread across the continent of Africa (Brautigam 2010:178). Also in the aspect of Agro-business, farmers from China have succeeded in establishing farms in places like Ghana (Afienya farm) and Nigeria (the Green Agricultural West Africa limited, GAWA) (Jiao, 2015:4).

Furthermore, a study conducted by Chen, Sun, Ukaejiofo, Xiaoyang and Brautigam on Learning from China? Manufacturing, Investment and Technology Transfer in Nigeria (2016) contains a list of Chinese investments in Nigeria covering automobile, steel manufacturing, furniture, etc. For the automobile, they include the FAW in Calabar and Jinan in Lekki which specialized in the assembly of heavy-duty trucks; for steel manufacturers, some have registered and now operate in different places like Ogun Edo and Lagos states. While Chinese investment in furniture includes the Bedmate and Lifemate furniture firms located in Lagos. There is also a Winghan firm that produces furniture items in Nigeria (Chen, Sun, Ukaejiofo, Xiaoyang and Brautigam (2016:10). 
Besides these, Sinomach, a state-owned Chinese conglomerate of over 50 companies had its subsidiaries signed several agreements with a number of African states for the following investments: $£ 240$ million sport facilities in Cameroon; a medium and low voltage power grid modernization program in Malabo, Equatorial Guinea; a city electricity network reconstruction project in Kenya; The USD970 million Morupule power plant in Rwanda; The RMB 976 million Mabodiroka Hydropower plant in Madagascar; The Power Transmission line for the Imboulu Hydropower station in Congo-Brazzaville; An USD647 million power transmission and distribution system for 25 cities to be supplied by Djibloho Hydropower station in Equatorial Guinea; An USD298 million electrification project in Luanda, Angola and an USD669 million engineering, procurement, and construction project to two privately own financial Hydropower states on the Kalungwishi River in Zambia (Brautigam, 2010:181).

\section{Training Assistance}

Apart from the scholarship programmes which African students have benefitted generously from the Chinese government, Government officials from African nations have also received training assistance from China through their short-term training course which was initiated in 1998 and took off fully in 2000 after the first FOCAC meeting (Tugendhat, 2014:1). The courses which aimed at "vigorously promoting further China-Africa cooperation in human resources development so as to promote the common development of China and Africa, offered 539 training courses in 2013 to government officials across developing countries. Of these numbers, 430 courses involved African officials: 139 courses were aimed exclusively at African officials: 73 of the courses for African officials were specifically for French officials (Tugendhat, 2014:4). The above source also reported that 15 of the trainings were targeted at agriculture, fisheries, animal husbandry or green growth.

\section{Job Creation and Transfer of Skills}

A study conducted by the trio of Sun Jayaram and Kassiri (2017) highlights three main economic benefits of Chinese activities to Africa as follows: job creation and skills development, transfer of new technology and knowledge, and financing and development of infrastructure. Consequently, out of over 1,000 companies they surveyed, "89 percent of employees were African, adding up to more than 300,000 jobs for African workers. Scaled up across all 10,000 Chinese firms in Africa, these numbers suggest that Chinese-owned businesses already employ several million Africans' (Sun, Jayaram and Kassiri in 2017:11). For instance, Twyford, a Chinese ceramic tile factory in Kenya has 1,500 workers at its factory in Kenya. These employees are not just engaged in manual labour; many of them work as technical operators at the Keda's advanced machinery. Most of the factories' management and supervisor, including its overall manager come from Kenya (Sun, Jayaram and Kassiri 2017:7). They also documented that:

Nearly two-thirds of Chinese employers provide some kind of skills training. In companies engaged in construction and manufacturing where skilled labor is a necessity, half offer apprenticeship training. Half of Chinese firms have introduced a new product or service to the local market and one-third has introduced a new technology. In some cases, Chinese firms have lowered prices for existing products and services by as much as 40 percent through improved technology and efficiencies of scale. Chinese construction contractors 
command around 50 percent of Africa's international engineering, procurement, and construction (EPC) market. (Sun, Jayaram and Kassiri, 2017:11).

Chen, Sun, Ukaejiofo, Xiaoyang and Brautigam (2016:11) whose study has to do with technology transfer in Nigeria earlier cited equally revealed that in most of the Chinese firms sampled in Nigeria, 80 percent of the workforce were engaged locally. Again, as Linyan (2012) noted during the construction of the African Union Headquarters, 1000 Ethiopians were employed directly on the site by the Chinese contractors. Thus, adding to the numbers of employed workers in Africa. All this goes to show how China's presence in Africa has benefited the continent in the areas of skills development and job creation/employment.

It is pertinent to add that China is also contributing to the peace and security of Africa with the deployment of 2,500 troops and police officers of which 1,051 are being stationed in South Sudan, 670 in Liberia and 402 in Mali with further pledges of \$100 million support for the African Union standby peacekeeping force (Ehinzuelen, 2017:4).

\section{The Challenges}

Despite these overwhelming gains, there are certain issues many scholars have expressed some worries about when it comes to China's engagement with the continent of Africa. These issues, which need urgent action for a healthy and sustainable relationship include: human right abuse, which China has been accused of committing; political influence following the suspension of presidential term limits; job loss due to competition; etc. We shall elaborate on these and many more.

\section{Issues of Human Rights Abuse}

One fear that has been entertained by many regarding China's engagement in African is the issue of China's stance on human rights which observers believe it has less regard for. For instance, China, not minding the human right abuse by the Sudanese Government that warranted the UN to impose sanctions on Sudan, went ahead to support the regime with investment worth almost $\$ 150 \mathrm{~m}$ in 2004 , three times as much as any single country. Even when American and Canadian oil companies decided to quit the country, China quickly stepped in, drilling wells, building pipelines, roads and armaments factories (The Economist, 2006:54). In Zimbabwe, after the launch of Operation Murambatsvina in 2005, 700,000 homes and businesses were destroyed by China who was in charge of the operation. But "China neutered all attempts at discussions, let alone condemnation, in the UN Security council" (The Economist, 2006:55). Abuse of workers' rights has been reported in some places in Africa where the Chinese companies are operating. For example, the ill-treatment allegedly meted out to workers in a mine owned by Chinese in Zambia in July 2006 led to violent protest that resulted in the deaths of some workers (The Economist, 2006; Human Right Watch, 2011)

\section{Job Loss due to Competition}

China's presence in Africa has also brought about unhealthy competitions which lead to job loss by local manufacturers. This stems from the fact that China, being a technologically advanced nation, can afford to mass- produce goods and sell at a cheaper rate and still make profit, which most African countries, if not all, cannot. Today, in most streets in Africa, Chinese products ranging from electronics, clothes, to plastics etc, are on sale at a very cheaper price thereby forcing people to patronize them instead of the local products. This trend has affected 
the local industries as a recent report has it that the South African steel industry is under threat of collapse as local producers struggle to compete with imports from China following the rise in steel production in 2016 (Sun, Jayaram and Kassiri, 2017:46). For instance, in 2015, "Evraz Highveld Steel and Vanadium Limited shut down, retrenching more than 2,000 employeeson top of some 11,000 jobs lost across the South African steel and engineering industries". (Sun, Jayaram and Kassiri, 2017:47).

\section{Wrong Political Influence}

According to Staden (2018) the Parliament in China voted in March, 2018 to suspend the presidential term limits in favour of the incumbent, President Xi Jinping. The extension of tenure is not the main issue of concern as every country is sovereign and it is expected to act accordingly. However, as observed by the above cited author, China's operations under President Xi both within and outside the country have been driven by the ideology of the Communist Party of China (CPC), part of which is to influence young Africans through education and training. This country has demonstrated by giving several scholarships to African students to study free in China. In 2013, President Xi called for the exclusion of socalled Western ideas from the universities curricula (Staden, 2018). So, the fear is that since China is not interested in promoting democracy in any way (The Economist, 2006:54), it is possible to influence Africa to follow suit since they have considered China as a "model" to follow.

\section{Spying Accusation and Loss of Confidence}

There is a recent report that suggests some loss of confidence on the part of the Africa Union (AU), Ethiopia and Algeria over the allegation that China is spying on the Union's activities through the building it donated to the Union. This followed a report of investigation published by a French newspaper Le Monde which claimed that China who paid and built the AU computer centre allegedly inserted a "backdoor" that allows it to transfer data (Dahir, 2018). The discovery came when technicians noticed an unusual peak in data usage between midnight and 2 am every night. An investigation revealed that the Union confidential data was being copied onto servers in Shanghai. As a result of this development, "the AU has allegedly acquired its own server and refused Chinese offers to reconfigure them. Algeria and Ethiopia officials also combed through the building, checking for suspicious materials and microphones" (Dahir, 2018).

\section{Piling up Debt Traps through Interest Free Loans}

China is noted for giving interest free loans to African countries to help develop their infrastructure and other needs. However, there have been accusations that such loans are rather debt traps which in a long run will have grave consequences on the economies of the Third World countries. The recent accusation was from the immediate past US Secretary of State, Tillerson Rex, who noted that "Beijing encourages dependency using opaque contracts, predatory loan practices and corrupt deals that mire nations in debts and undercut their sovereignty, denying them their long-term, self-sustaining growth.... Chinese investment does have the potential to address Africa's infrastructure gap, but its approach has led to mounting debt and few, if any, jobs in most countries" (Tim 2018). 


\section{CONCLUSION}

The study discussed China's presence in Africa and well as the African response to this development. It also pointed out some of the internal factors that propelled the engagement by both sides. Thus, on the side of China, it was the stable economy as a result of intensive reforms, experience, shrinking of arable land, the declining farming population, and the needs for raw materials to sustain the economic and industrial growth back home. For Africa, it was the desire to find permanent solutions to the myriad of domestic challenges, including poor infrastructure like roads, railways and electricity. Also, poverty, loan facilities, investment and the desire for technology to harness the resources on its soil, etc., influenced Africa towards this engagement. Moreso the study noted that since the engagement, Africa has benefited copiously from the Chinese largesse as China has assisted her to build roads networks, railways and power infrastructure, giving scholarship to its citizens to study in China universities, transferring technology, trading with and investing in Africa, generating employment opportunities for African citizens, granting free interest loans, cancelling debts, among others. This, however, is not without challenges. As a result, the paper highlighted the flip side in the engagement- some of which are emerging- to include, human rights abuse, wrong political influence, accumulation of debt traps for Africa through interest free loans, loss of confidence due to spying accusation through the African Union headquarters' facilities as well as job loss owing to competitions. These challenges can affect the relationship between the two parties if not handled with care. We believe that China- African engagement is vital for the growth and development of each other as such the following recommendations have been considered germane in enhancing and further cement the engagement:

\section{RECOMMENDATIONS}

1. Efforts should be made to sustain the relationship in such a way that both sides can benefit. This could be attained by being open and transparent in all the dealings by both parties.

2. African states should seize the current opportunity of their engagement with China to develop their needed infrastructure and acquire the necessary skills and knowledge for their economic and industrial growth, because delay may be dangerous.

3. Africa must also learn to diversify its economy by not relying solely on commodities which the Chinese are in need of. In this way, she will be able to satisfy the needs of other countries who may want different resources from Africa, thereby generating money for the economy.

4. China should write its name in the annals of African technological breakthroughs by genuinely transferring technology to African for self-reliance and development.

5. All the issues considered as flip side in this study must be looked into, especially the issues of human rights abuse, wrong political influence and piling up of debt for the unborn generations.

6. Finally, we believe that there is no engagement anywhere in the world that is devoid of issues. But it is the ability to resolve them is what determines the texture and contour of such engagement. Therefore, they must work hard to ensure any issue that may arise between them, including the spying allegation leveled against China. 


\section{REFERENCES}

Ambe-uva, T. N. (2014): South-South Cooperation. Lagos: National Open University of Nigeria (NOUN).

Anyagafu, V. (2018) “Africa Remains Indispensable for Achieving China-Africa 2030 Agenda- President Xi"

https://www.google.com.ng/amp/s/www.vangaurdngr.com/2018/03/africa-remainsindispensable-towards-achieving-china-africa-2030-agenda-president-xi/amp/ (Accessed on 23/10/2018)

Brautigam, D. (2010) "Looking East: African Newest Investment Partners" Global Journal of Emerging Market Economies Vol. 2(2) (2010) 173-188. London: SAGE Publications. DOI:10.1177/097491011000200205

Brautigam, D. (2013) “China Africa EC. and Trade Coop. White Paper, 2013”. Monday September, 23, 2013. Available at: www.chinaafricarealstory.com/2013/09/chinaafrica-economic-and-trade.html?m=1 (Accessed in April, 2018)

Brautigam, D. and Jyhjong, H. (2016) "Eastern Promises: New Data on Chinese Loans in Africa, 2000-2014". Working Paper No.2016/4. China Africa Research Initiative, School of Advanced International Studies, John Hopkins University Washington, DC. Retrieved from http://www.sais-cari.org/publications (Accessed on 20/08/2018)

Breeze, V. and Moore, N. (2017) "China Tops US and UK as Destination for Anglophone African Students. The Conversation. Available at: http://theconversation.com/chinatops-us-and-uk-as-destination-for-anglophone-african-students-78967 (Accessed in April, 2018)

CARI (2018) Data: Chinese Loans to Africa" Available at https://sais-cari.org/data-chineseloans-and-aid-to-africa (Accessed in April, 2018)

Chin, Y., Sun, I. Y., Ukaejiofo, R. U., Xiaoyang, T. and Brautigam, D. (2016) "Learning from China? Manufacturing, Investment and Technology Transfer in Nigeria" Working Paper No.2016/2. China Africa Research Initiative, School of Advanced International Studies, John Hopkins University Washington, DC Retrieved from http://www.sais.cari.org/publications (Accessed on 20/08/2018)

China-Africa Economic Trade Cooperation (CAETC, 2013) Information Office of the State Council, the People's Republic of China, August 2013, Beijing

Dahir, A. L. (2018) "China 'Gifted' The African Union Headquarters Building and then Allegedly bugged it for State Secrets" in Quartz. Available at: https://.com/1192493/china-spied-on-african-union-headquarters-for-five-years/

Dauda, S. (2015) Foreign Policy: Formulation and Analysis. Abuja: Zumunta Publications.

Ehinzuelen, M. M. (2017) "African Drives in Snowballing Engagement with the hinese: The case of Nigeria." J. Glob Econ. 5:274.doi10.4172/2375-4389.1000274

Hirst, T. (2015) "A Brief History of China's Economic Growth" Available at https://www.weforum.org/agenda/2015/07/brief-history-ofchina-economic-growth/ (Accessed on 19-082018)

Human Right Watch (2011) "You'll be fired if you refused: Labour Abuses in Zimbabwe's Chinese State Owned Copper Mine." http://www.hrw-org/report/2011/11/04/youll-befired-if-you-refued/labour-abuses-zimbabwe-chinese-state-owned-copper-mines

Jiao, Y. (2015) "Chinese Agricultural Entrepreneurship in Africa: Case Studies in Ghana and Nigeria” Policy Brief No.05/2015. The SAIS. China-Africa Research Initiative, John Hopkins University. 
Linyan, W. "New Headquarters Shows Partnership Entering Era of Hope: Ethiopia P" China Daily 01/30/2012 www.chinadaily.com.cn/cndy/2012-01/30/content_14502354.htm Accessed on $19 / 08 / 2018$

Marqures, J. and Spanakos, A. (2014) "South-South Relations and English School of International Relations: Chinese and Brazilian Ideas and Involvement in SubSaharan Africa" Rev. Bras.polit.57(Special Edition):138-156(2014) http://dx.doi.org/10.1590/0034-7329201400209

OECD, (2015) "China in the Changing Global Environment." www.oecd.org/publishing/corrigenda Accessed on 22/10/2018

Ogbu, S. O. (2018) The Travails of African Underdevelopment: Prospects for Development. $B$ eing the $28^{\text {th }}$ Inaugural Lecture of the University of Abuja on Thursday $29^{\text {th }}$ March, 2018

Staden, C. V. (2018) "How the Extended Rule of China's President Xi Jinping will Influence Africa's Future?" South Africa: South African Institute of International Affairs.

Sun, I. Y., Jayaram, K. and Kassiri, O. (2017) "Dance of the Lions and Dragons: How are Africa and China Engaging, and how will the participation Evolve?" Mckinsey \& Company

Sun, Y. (2018) "Foresight Africa Viewpoint-China's Engagement in Africa: What can we learn in 2018 from the $\$ 60$ billion Commitment?" Brooking African in Focus, Tuesday January, 30, 2018. Available at: https://www.brookings.edu/blog/Africa-infocus/2018/01/30/foresight-africa-viewpoint-chinas-engaging-in-africa-what-can-welearn-in-2018-from-the-60-billion-commitment/ (Accessed in April, 2018)

The Economist (2006) "China's Scramble for Africa". October $28^{\text {th }}$-November $3^{\text {rd, }} 2006$.

The Herald, (2017) "Africa reaps Benefits of close Ties with China" https://www.google.com.ng/amp/s/www.herald.co.zw/africa-reaps-benefits-of-closeties-with-china/amp/ Accessed on 19/08/2018

Tim, F. (2018): "Eight Countries in Danger of Falling into China's 'Debt Trap"' in Quartz https://www.google.com/amp/s/qs.com/1223768/china-debt-trap-these-eight-countriesare-in-danger-of-debt-overloads-from-chinas-belt-and-road-plans/amp/ (accessed on 23/08/2018

Tugendhat, H. (2014) "Chinese Training Courses for African Officials: A Win-Win Engagement?" Policy Brief No.03, 2014, China-Africa Research Initiative at John Hopkins University.

VOA (2018) Africa Faces Some Risks with China's Investments Https://www.com/ng/amp/learningenglish.voanews.com/amp/4482082.html (Accessed on $19 / 08 / 2018$ ) 